\title{
Eukaryotic phylotypes in aquatic moss pillars inhabiting a freshwater lake in East Antarctica, based on 18S rRNA gene analysis
}

\author{
Ryosuke Nakai - Takashi Abe $\cdot$ Tomoya Baba $\cdot$ Satoshi Imura \\ Hiroshi Kagoshima · Hiroshi Kanda · Yuji Kohara • Akiko Koi • \\ Hironori Niki $\cdot$ Katsuhiko Yanagihara $\cdot$ Takeshi Naganuma
}

Received: 2 December 2011/Revised: 5 April 2012/Accepted: 17 April 2012/Published online: 3 May 2012

(C) The Author(s) 2012. This article is published with open access at Springerlink.com

\begin{abstract}
Aquatic mosses of Leptobryum species form unique tower-like pillars of vegetation termed "moss pillars" in Antarctic lakes. Moss pillars have distinct redoxaffected sections: oxidative exteriors and reductive interiors. We have proposed that a "pillar" is a community and habitat of functionally interdependent organisms and may represent
\end{abstract}

Electronic supplementary material The online version of this article (doi:10.1007/s00300-012-1188-1) contains supplementary material, which is available to authorized users.

R. Nakai · A. Koi · T. Naganuma ( $\square)$

Graduate School of Biosphere Science, Hiroshima University, 1-4-4 Kagamiyama, Higashi-Hiroshima,

Hiroshima 739-8528, Japan

e-mail: takn@hiroshima-u.ac.jp

R. Nakai

Japan Society for the Promotion of Science,

Chiyoda-ku, Tokyo 102-8471, Japan

Present Address:

R. Nakai

National Institute of Genetics, 1111 Yata, Mishima,

Shizuoka 411-8540, Japan

T. Abe

Graduate School of Science and Technology, Niigata University, 8050 Ikarashi 2-no-cho, Nishi-ku, Niigata 950-2181, Japan

T. Baba $\cdot$ H. Kagoshima $\cdot$ H. Niki $\cdot$ K. Yanagihara

Transdisciplinary Research Integration Center,

4-3-13 Toranomon, Minato-ku, Tokyo 105-0001, Japan

S. Imura $\cdot$ H. Kanda

National Institute of Polar Research, 10-3 Midori-cho,

Tachikawa, Tokyo 190-8518, Japan

H. Kagoshima · Y. Kohara · H. Niki

National Institute of Genetics, 1111 Yata, Mishima,

Shizuoka 411-8540, Japan a mini-biosphere. Batteries of 16S rRNA genotypes, or phylotypes, of eubacteria and cyanobacteria, but no archaea, have been identified in moss pillars. However, detailed identification or phylogenetic analyses of the moss and their associated eukaryotic microbiota have not been performed. This study analyzed near-full-length 18S rRNA gene sequences obtained from two whole moss pillars. In total, 28 PCR clone libraries from two whole moss pillars were constructed, and 96 clones from each library (total 2,688 clones) were randomly selected and sequenced. Molecular phylogenetic analysis revealed that the phylotype belonging to Bryophyta, considered to be derived from moss, was closely related $(99.9 \%)$ to the $18 \mathrm{~S}$ rRNA gene sequence from Leptobryum pyriforme. Unexpectedly, phylotypes belonging to a novel clade of fungi dominated (approximately $27-75 \%$ ) the moss pillar libraries. This suggests that fungi may contribute to carbon cycling in the moss pillar as parasites or decomposers. In addition, phylotypes related to ciliates and tardigrades were subdominant in the exterior, while the phylotype of the ameba-like, single-celled eukaryote, Cercomonas (Cercozoa), was detected only in the interior. These features were shared by both moss pillars. The $18 \mathrm{~S}$ rRNA gene-based profiles demonstrated that redox-related factors may control distribution of some eukaryotic microbes in a whole moss pillar.

Keywords Antarctic lake - Moss pillars - Biodiversity · 18S rRNA gene $\cdot$ Eukaryote $\cdot$ Phylogenetic analyses

\section{Introduction}

Several lakes with varying water qualities, ranging from freshwater to hypersaline, are present in the ice-free areas along the continental margin of Antarctica (Imura et al. 
2003; Gibson et al. 2006). These lakes are model sites for limnological and ecological studies investigating the effects of recent global environmental changes (Convey 2006, 2011; Laybourn-Parry 2009). Lake bottoms are known to contain microbial mats consisting of algae such as cyanobacteria, diatoms, and green algae (Vincent 1988, 2000). The lakes around the Syowa Station, situated in East Antarctica, were reported to have a large moss community known as "moss pillars," containing not only algae but also the aquatic moss of the genus Leptobryum (Imura et al. 1999). Moss pillars are unique biological communities forming towerlike structures and originating from algal mats on the lake bottom, with large pillars being $40 \mathrm{~cm}$ in diameter and $80 \mathrm{~cm}$ in height (Imura 2006). It is not uncommon for bryophytes to form communities on lake bottoms, and such communities have been reported in polar regions, including Greenland, King George Island and Livingston Island (South Shetland Islands, Antarctica), and the Dry Valleys (continental Antarctica) (Quesada et al. 2008). However, unusual structures such as moss pillars have not been reported in regions other than Antarctica, making them extremely unique ecosystems.

Since the first description of moss pillars by Imura et al. (1999), much work has been conducted, including the estimation of growth rate by radiocarbon $\left({ }^{14} \mathrm{C}\right)$ dating (Imura et al. 2000), moss species and attached algae (Ohtani et al. 2001), distribution of aquatic mosses around Syowa Station (Imura et al. 2003), carbon, nitrogen, and chlorophyll $a$ contents (Kudoh et al. 2003a; Imura 2006), temperature and light environment of the moss habitat (Kudoh et al. 2003b; Tanabe et al. 2008), and photochemical activities of apices and sides of pillars (Kudoh et al. 2003c, 2009). Dating of lake sediments revealed that lakes in the ice-free areas around Syowa Station have been formed in the few 1,000 years since the retreat of ice sheets following the end of the last ice age (Iwasa et al. 2000; Matsumoto et al. 2006). Kimura et al. (2010) were the first to describe the vertical profiles of temperature, salt content, dissolved oxygen, and $\mathrm{pH}$ in the Lake Hotoke-Ike where moss pillars were found, clearly showing the existence of thermocline and salinocline between water depths of 1-2 m. Furthermore, long-term, continuous observations of the lakes indicated that this stratification disappeared immediately after the ice covering on the lake surfaces melted in summer (Tanabe et al. 2008; Kudoh et al. 2009).

The exterior of moss pillars is green; the apices in particular are bright green with adherent oxygen bubbles (Imura et al. 2000). It is likely that the top surface of a moss pillar is in a state of oxygen oversaturation because of active photosynthesis by the moss and algae. Microscopic observations showed that the cyanobacterium Leptolyngbya sp. and the green algae Oedogonium sp. and Cosmarium sp. are attached to the sides of moss pillars (Ohtani et al. 2001). However, the interior is packed with brown plant residues and gives off a strong odor of sulfur compounds, and thus, it is considered that an oxygen gradient exists between the exterior and interior (Kudoh et al. 2003a). Nakai et al. (2012) detected phylotypes distributed throughout moss pillars and those in each layer, using fatty acid analysis and molecular phylogenetic analysis based on the 16S rRNA gene. Thus, bacterial communities differ between the exterior and interior of moss pillars and are hypothesized to participate in biogeochemical processes of elements such as carbon, nitrogen, and sulfur.

Knowledge is growing about the morphological and limnological features of Antarctic moss pillars and their bacterial species composition. However, with regard to mosses and the eukaryotic microbiota, only microscopic observations have been reported and no detailed identifications have been performed. Mosses are the major components of moss pillars. In addition, their associated eukaryotic microbiota are considered to play a key role in the production and decomposition of organic matter. We used molecular phylogenetic analysis based on the $18 \mathrm{~S}$ rRNA gene to elucidate the phylogeny and diversity of mosses and eukaryotic microbiota comprising these unique ecosystems in Antarctic lakes. Our findings will enable further discussion of the phylogeography of mosses and eukaryotic microorganisms in polar environments.

\section{Materials and methods}

\section{Study area}

Antarctic moss pillar specimens were harvested on January 19, 2000, during the 42nd Japanese Antarctic Research Expedition, at Lake Hotoke-Ike $\left(69^{\circ} 28^{\prime} \mathrm{S}, 39^{\circ} 34^{\prime} \mathrm{E}\right)$, Skarvsnes, about $50 \mathrm{~km}$ south of Syowa Station in East Antarctica (Fig. 1). The water quality of the lake has been described previously (Kudoh et al. 2003b). Two specimens were harvested gently by SCUBA diving. Specimen A was $22 \mathrm{~cm}$ in diameter and $30 \mathrm{~cm}$ in height. Specimen B, which was used to compare moss species and eukaryotic diversity between samples, was $20 \mathrm{~cm}$ in diameter and $27 \mathrm{~cm}$ in height. The specimens were gently placed in buckets containing lake water and sealed tightly. The moss pillars are essentially composed of long moss shoots. They are considerably firm structures that are soft, but not fragile. The specimens were immediately and gently transported to the laboratory on board the icebreaker Shirase by a helicopter. After ensuring the structural integrity of the specimens, they were stored in a freezer $\left(-20^{\circ} \mathrm{C}\right)$ until further analysis.

DNA extraction and PCR amplification

Each frozen moss pillar specimen was thawed partially and sectioned into 14 samples ( 7 exterior, 7 interior) by 
Fig. 1 Map of the study site. Lake Hotoke-Ike, formerly known as Lake B-4-Ike, is located in the Skarvsnes ice-free area near Syowa Station in East Antarctica. Black areas represent the ice-free areas

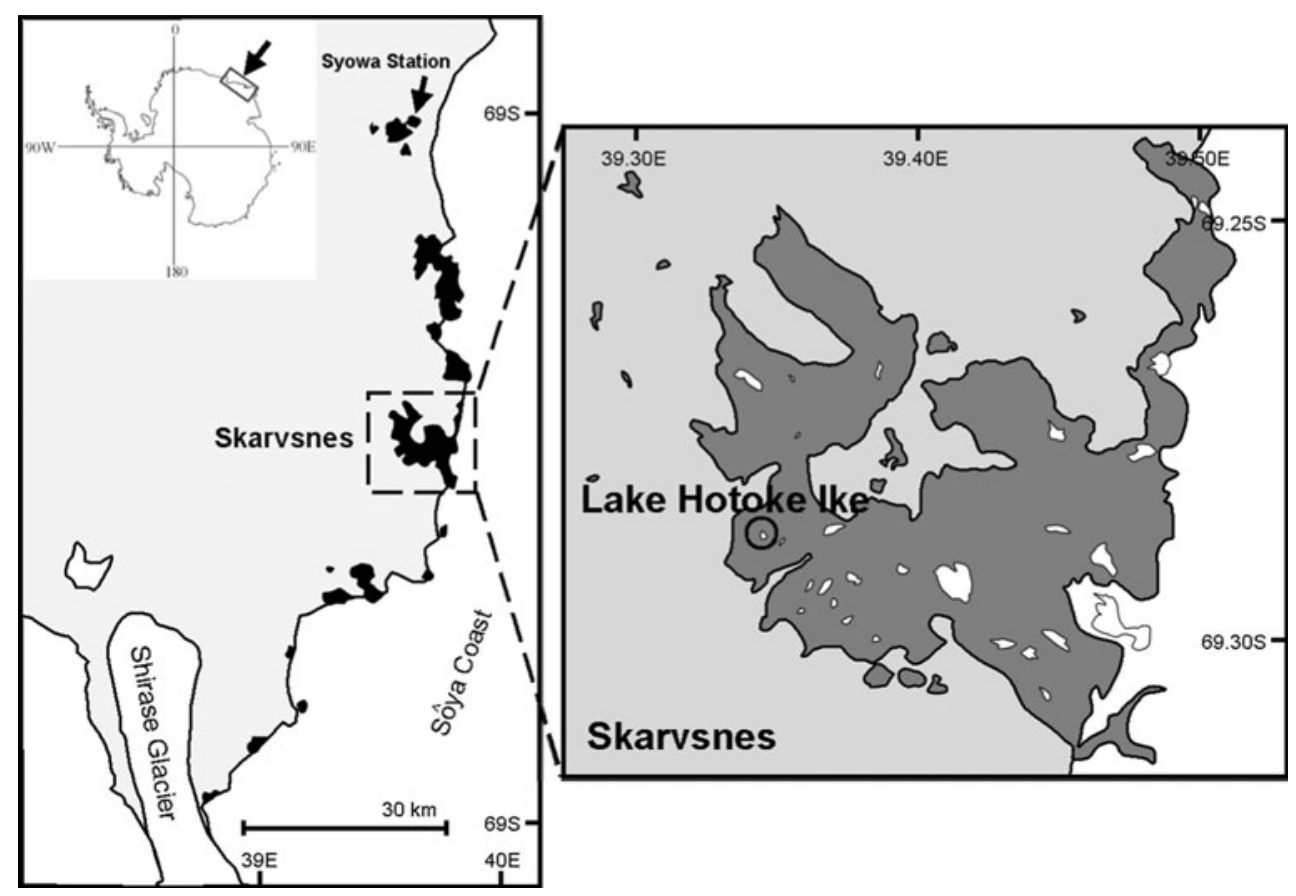

separating the interior from the exterior layer and dividing each specimen longitudinally into 7 horizontal sections. A sterile knife was used for sectioning the specimens. Exterior sections were labeled $\mathrm{O} 1-\mathrm{O} 7$, and interior sections were labeled I1-I7, as described previously (Nakai et al. 2012). Sections were prepared by freeze-drying and then grinding with a sterilized mortar and pestle. DNA was extracted by applying a partially modified version of the bead-beating method reported by Miller et al. (1999) to $500 \mathrm{mg}$ (dry weight) of each sample. Briefly, a subsample (100 mg dry weight) was placed in a 2-mL screw-cap microtube, with $1.2 \mathrm{~g}$ of sterilized zirconium/silica beads (BioSpec Products Inc., Bartlesville, OK, USA), $0.3 \mathrm{~mL}$ of phosphate buffer (100 $\left.\mathrm{mM} \mathrm{NaH}_{2} \mathrm{PO}_{4}, \mathrm{pH} 8.0\right), 0.3 \mathrm{~mL}$ of lysis buffer $(10 \%$

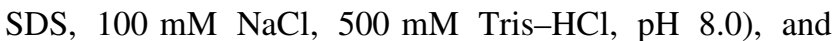
$0.3 \mathrm{~mL}$ of chloroform-isoamyl alcohol (24:1). A Mini Bead Beater 8 (BioSpec Product) was used at 3,200 rpm for $3 \mathrm{~min}$ to lyse cells. Beads and broken cell fragments in the tube were then removed by centrifugation (15,000 rpm, $5 \mathrm{~min})$. The supernatant was purified using a Mag ExtractorGenome kit (Toyobo, Osaka, Japan) following the manufacturer's instructions. A PCR clone library was generated from the 18S rRNA gene in the purified genomic DNA. Euk-F and Euk-R were used as PCR primers to amplify the near-full-length 18S rRNA gene (Medlin et al. 1988). PCR conditions followed DeLong (1992).

Our aim was to examine the presence and distribution of not only the major component species, genus Leptobryum, but also the minor component species, genus Bryum, in moss pillars. For this, the forward primer Bry-F (5'-ACA AACTCCCGACTCCGG- ${ }^{\prime}$ ) and the reverse primer
Bry-R (5'-GATTACCCAGGCCTACCG-3') were designed using the 18S rRNA gene sequences for $B$. capillare (AF205945), B. donianum (AF023704), B. caespiticium (AF023703), B. alpinum (AF023700), and B. argenteum (BAU18529). The PCR-amplified product was approximately 1,300 bp in length. PCR conditions were as follows: initial denaturation at $95{ }^{\circ} \mathrm{C}$ for $2 \mathrm{~min}$, followed by 30 cycles of denaturation at $95{ }^{\circ} \mathrm{C}$ for $1 \mathrm{~min}$, annealing at $57{ }^{\circ} \mathrm{C}$ for $1 \mathrm{~min}$, and extension at $72{ }^{\circ} \mathrm{C}$ for $1.5 \mathrm{~min}$.

Construction of clone libraries and sequence analyses

The PCR-amplified products were cloned using the TOPO TA cloning kit (Invitrogen, Carlsbad, CA, USA) before transformation in Escherichia coli TOP10 (Invitrogen). The nucleotide sequences of inserted 18S rRNA genes were determined using an ABI 3730XL automatic DNA sequencer (Applied Biosystems, Foster City, CA, USA). To obtain near-full-length 18S rRNA gene sequences, M13F, M13R, and Euk516F (Amann et al. 1990) primers were used for DNA sequencing. Similar sequences were clustered into phylotypes using the CD-HIT program (Li and Godzik 2006; Huang et al. 2010) with a minimum identity of $97 \%$. These phylotypes were checked for chimeras using RDPII chimera detection (Maidak et al. 2001) and Bellerophon (Huber et al. 2004). Each phylotype was compared with known 18S rRNA gene sequences by BLASTN search (Altschul et al. 1997) against the NCBI nt-database. MEGA 5.0 (Tamura et al. 2011) was used for maximum likelihood analyses using the GTR nucleotide substitution model. The rarefaction analysis of microbial diversity was completed using the Rarefaction Calculator 
(http://www.biology.ualberta.ca/jbrzusto/rarefact.php). The 18S rRNA gene sequences of the phylotypes obtained from the PCR clone library analysis were deposited in the DDBJ/ EMBL/GenBank database, under the accession numbers AB695444 to AB695539.

\section{Results and discussion}

Eukaryotic diversity in moss pillars based on 18S rRNA gene sequences

The eukaryotic 18S rRNA gene was detected by PCR amplification in all samples from both moss pillars. A total of 1,344 clones were obtained from specimen A for analysis, of which 1,112 could be used for phylotyping after excluding unclear sequence waveforms and chimeric sequences. Phylotyping ( $\geq 97 \%$ ) of these 1,112 clones yielded 52 phylotypes. Phylogenetic classification separated the 52 phylotypes into the following 9 phylotype groups: 1 Bryophyta, 13 Alveolata (1 Apicomplexa, 10 Ciliophora, 2 unclassified Alveolata), 7 Amoebozoa (1 Mycetozoa, 2 Tubulinea, 4 unclassified Amoebozoa), 1 Chlorophyta, 7 Fungi, 8 Metazoa (1 Nematoda, 2 Platyhelminthes, 1 Rotifera, 2 Tardigrada, 2 unclassified Metazoa), 3 Rhizaria, 2 Rhodophyta, 10 Stramenopiles (1 Chrysophyceae, 2 Dictyochophyceae, 1 Hyphochytriomycete, 3 Labyrinthulida, 1 Oikomonadaceae, 1 Oomycete, and 1 unclassified Stramenopile) (Table 1; distribution, phylogenetic classification, and BLASTN homology search results for each phylotype in the 14 samples are shown in Table S1; the phylogenetic tree of phylotypes is shown in Fig. S1).

It was found that the phylotypes belonging to Bryophyta and Fungi dominated the moss pillar libraries. Primary producers such as Chlorophyta and Rhodophyta were also detected. These algae have been identified using microscopic observations (Ohtani et al. 2001). In addition, phylotypes related to ciliates and tardigrades were found to be subdominant in the exterior, while the phylotype of the ameba-like, single-celled eukaryote, Cercomonas (Cercozoa), was detected only in the interior. This suggests that the exterior and interior of moss pillars have common eukaryotic phylotypes as well as characteristic phylotypes unique to each layer. This layer-specific distribution of phylotypes reflects the double-layered structure comprising an oxidative exterior and a reductive interior. Kudoh et al. (2009) reported that hydrogen sulfide gas was not detected in the water column and at the surface of the phytobenthos in Lake Hotoke-Ike; however, $\geq 1 \mu \mathrm{g} \mathrm{g}^{-1}$ (wet weight) of hydrogen sulfide gas was detected from deeper than $5 \mathrm{~mm}$ within the phytobenthos mat samples. This suggests that the subsurface interior part remains in anoxic condition. The previous $16 \mathrm{~S}$ rDNA cloning analysis also detected the gram-positive obligate anaerobe Clostridium only in the interior of the pillar (Nakai et al. 2012). Thus, moss pillars are considered to create very suitable environments for algae and other small animals such as ciliates and tardigrades. Rarefaction analysis revealed that biodiversity of the exterior could be higher than that of the interior (Fig. 2). This lower biodiversity may be reflected by the more restrictive environmental conditions, such as anoxic conditions in the inner part of the pillars.

If the $18 \mathrm{~S}$ rRNA genes of all eukaryotes were equally easily amplified and all had similar copy numbers, then the proportion of sequences from different phylotypes at the end of a PCR run would reflect their abundance in the starting mixture. However, in reality, the copy number varies among taxa (Potvin and Lovejoy 2009) and the number has been correlated with the genome size (Zhu et al. 2005). Larger cells tend to contain more genomic DNA (Cavalier-Smith 2005). This may have affected our results.

Bryophyta detected in moss pillars

The 235 sequences belonging to Bryophyta (approximately $21 \%$ of the total) were classified into a single phylotype (Table 1). The phylotype was obtained from all 14 samples (both interior and exterior layers) of the studied moss pillar (Table 1). The phylotype considered to be the major component species of the pillar had a $99.9 \%$ homology with the 18S rRNA gene sequence from Leptobryum pyriforme (X80980), the most closely related species with only 1 base mutation from the sequence in the database. This is in agreement with a previous study by Imura et al. (1999), which showed that the major component species of moss pillars belong to the genus Leptobryum. The existence of the genus Leptobryum in lakes around Syowa Station in East Antarctica was first reported by Nakanishi (1977). Furthermore, in the Skarvsnes area around Syowa Station, where moss pillars are found, the presence of the genus Leptobryum was confirmed in 24 individual lakes, of which 8 lakes were found to have moss pillar formations (Imura et al. 2003). Other reports of the genus Leptobryum are limited to lakes around the Indian stations in Schirmacher Oasis, situated at a distance of $1,000 \mathrm{~km}$ from Syowa Station (Tewari and Pant 1996). Thus, distribution of the genus Leptobryum is limited to lakes around Syowa Station and Indian stations, with no reports from any other lakes in Antarctica. One option for understanding the mechanism by which this genus has been established in these lakes would be to use phylogenetic analysis based on genes with faster evolutionary rates than the 18S rRNA gene and multiple $L$. pyriforme samples from different environments.

We attempted PCR amplification with the primers designed to detect 18S rRNA genes of the genus Bryum, but met with no success because of the detection limit. 
Table 1 Distribution of phylotypes and clones in the specimen A moss pillar sections

\begin{tabular}{|c|c|c|c|c|c|c|c|c|c|c|c|c|c|c|c|c|}
\hline \multirow[t]{3}{*}{ Phylogenetic group } & \multirow{3}{*}{$\begin{array}{l}\text { No. of } \\
\text { phylotype }\end{array}$} & \multirow{3}{*}{$\begin{array}{l}\text { No. of } \\
\text { clones }\end{array}$} & \multicolumn{14}{|c|}{ Distribution of clones } \\
\hline & & & \multicolumn{7}{|c|}{ Exterior section } & \multicolumn{7}{|c|}{ Interior section } \\
\hline & & & $\mathrm{O} 1$ & $\mathrm{O} 2$ & $\mathrm{O} 3$ & $\mathrm{O} 4$ & O5 & O6 & $\mathrm{O} 7$ & I1 & $\mathrm{I} 2$ & I3 & I4 & I5 & I6 & $\mathrm{I} 7$ \\
\hline Bryophyta & 1 & 235 & 19 & 29 & 5 & 9 & 6 & 7 & 5 & 28 & 22 & 31 & 20 & 27 & 20 & 7 \\
\hline Alveolata & 13 & 92 & 0 & 6 & 8 & 2 & 15 & 1 & 16 & 9 & 0 & 1 & 7 & 12 & 13 & 2 \\
\hline Apicomplexa & (1) & (8) & $(0)$ & (1) & $(0)$ & $(0)$ & (1) & (1) & (5) & $(0)$ & $(0)$ & $(0)$ & (0) & $(0)$ & $(0)$ & $(0)$ \\
\hline Ciliophora & (10) & $(81)$ & $(0)$ & $(5)$ & (8) & (2) & (12) & $(0)$ & (10) & (9) & $(0)$ & (1) & (7) & (12) & (13) & (2) \\
\hline Unclassified Alveolata & (2) & (3) & $(0)$ & $(0)$ & $(0)$ & $(0)$ & (2) & $(0)$ & (1) & $(0)$ & $(0)$ & $(0)$ & $(0)$ & $(0)$ & $(0)$ & $(0)$ \\
\hline Amoebozoa & 7 & 29 & 0 & 0 & 0 & 0 & 0 & 4 & 0 & 0 & 4 & 2 & 3 & 4 & 1 & 11 \\
\hline Mycetozoa & (1) & (1) & $(0)$ & $(0)$ & $(0)$ & $(0)$ & $(0)$ & $(0)$ & $(0)$ & $(0)$ & $(0)$ & $(0)$ & (1) & $(0)$ & $(0)$ & $(0)$ \\
\hline Tubulinea & (2) & (7) & $(0)$ & $(0)$ & $(0)$ & $(0)$ & $(0)$ & (3) & $(0)$ & $(0)$ & (1) & $(0)$ & $(0)$ & $(0)$ & $(0)$ & (3) \\
\hline Unclassified Amoebozoa & (4) & $(21)$ & $(0)$ & $(0)$ & $(0)$ & $(0)$ & $(0)$ & (1) & $(0)$ & $(0)$ & (3) & (2) & (2) & (4) & (1) & (8) \\
\hline Chlorophyta & 1 & 3 & 0 & 1 & 0 & 0 & 0 & 0 & 1 & 0 & 0 & 0 & 1 & 0 & 0 & 0 \\
\hline Fungi & 7 & 622 & 38 & 41 & 62 & 63 & 31 & 55 & 38 & 37 & 40 & 41 & 38 & 30 & 44 & 64 \\
\hline Metazoa & 8 & 85 & 20 & 8 & 2 & 4 & 24 & 7 & 12 & 2 & 3 & 2 & 1 & 0 & 0 & 0 \\
\hline Nematoda & (1) & (3) & (3) & (0) & $(0)$ & $(0)$ & $(0)$ & (0) & (0) & $(0)$ & $(0)$ & $(0)$ & (0) & $(0)$ & $(0)$ & $(0)$ \\
\hline Platyhelminthes & (2) & (4) & $(0)$ & $(0)$ & $(0)$ & (2) & $(0)$ & (1) & $(0)$ & $(0)$ & $(0)$ & $(0)$ & (1) & $(0)$ & $(0)$ & $(0)$ \\
\hline Rotifera & (1) & (1) & $(0)$ & (1) & $(0)$ & $(0)$ & $(0)$ & (0) & $(0)$ & $(0)$ & $(0)$ & $(0)$ & $(0)$ & $(0)$ & $(0)$ & $(0)$ \\
\hline Tardigrada & (2) & (71) & (12) & (7) & (2) & (2) & (23) & (6) & (12) & (2) & (3) & (2) & (0) & $(0)$ & $(0)$ & $(0)$ \\
\hline Unclassified Metazoa & (2) & (6) & $(5)$ & $(0)$ & $(0)$ & $(0)$ & (1) & $(0)$ & $(0)$ & $(0)$ & $(0)$ & $(0)$ & $(0)$ & $(0)$ & $(0)$ & $(0)$ \\
\hline Rhizaria & 3 & 10 & 0 & 0 & 0 & 0 & 2 & 0 & 0 & 0 & 2 & 1 & 4 & 1 & 0 & 0 \\
\hline Rhodophyta & 2 & 9 & 0 & 1 & 1 & 2 & 1 & 1 & 1 & 0 & 0 & 0 & 0 & 0 & 1 & 1 \\
\hline Stramenopiles & 10 & 27 & 4 & 1 & 4 & 1 & 3 & 3 & 6 & 1 & 1 & 0 & 0 & 3 & 0 & 0 \\
\hline Chrysophyceae & (1) & (3) & (3) & $(0)$ & $(0)$ & $(0)$ & $(0)$ & $(0)$ & $(0)$ & $(0)$ & $(0)$ & $(0)$ & $(0)$ & $(0)$ & $(0)$ & $(0)$ \\
\hline Dictyochophyceae & (2) & (3) & $(0)$ & (1) & $(0)$ & $(0)$ & $(0)$ & (2) & $(0)$ & $(0)$ & $(0)$ & $(0)$ & $(0)$ & $(0)$ & $(0)$ & $(0)$ \\
\hline Hyphochytriomycetes & (1) & (1) & $(0)$ & $(0)$ & $(0)$ & $(0)$ & $(0)$ & $(0)$ & (1) & $(0)$ & $(0)$ & $(0)$ & $(0)$ & $(0)$ & $(0)$ & $(0)$ \\
\hline Labyrinthulida & (3) & (12) & (1) & $(0)$ & (2) & (1) & (2) & (1) & (1) & (1) & (1) & $(0)$ & $(0)$ & (2) & $(0)$ & $(0)$ \\
\hline Oikomonadaceae & (1) & (1) & $(0)$ & $(0)$ & $(0)$ & $(0)$ & $(0)$ & $(0)$ & (1) & $(0)$ & $(0)$ & $(0)$ & $(0)$ & $(0)$ & $(0)$ & $(0)$ \\
\hline Oomycetes & (1) & (5) & $(0)$ & $(0)$ & $(0)$ & $(0)$ & (1) & $(0)$ & (3) & $(0)$ & $(0)$ & $(0)$ & $(0)$ & (1) & $(0)$ & $(0)$ \\
\hline $\begin{array}{l}\text { Unclassified } \\
\text { Stramenopiles }\end{array}$ & (1) & (2) & $(0)$ & $(0)$ & (2) & $(0)$ & $(0)$ & $(0)$ & $(0)$ & $(0)$ & $(0)$ & $(0)$ & $(0)$ & $(0)$ & $(0)$ & $(0)$ \\
\hline Total & 52 & 1112 & 81 & 87 & 82 & 81 & 82 & 78 & 79 & 77 & 72 & 78 & 74 & 77 & 79 & 85 \\
\hline Shannon index & & & 1.63 & 1.43 & 1.46 & 1.09 & 2.44 & 1.94 & 2.17 & 1.24 & 1.20 & 1.06 & 1.42 & 1.51 & 1.08 & 0.94 \\
\hline
\end{tabular}

Numbers from respective "Alveolata," "Amoebozoa," "Metazoa," and "Stramenopiles" phylotypes are in parentheses

A previous study also showed that the moss species in moss pillars mainly belong to the genus Leptobryum and that Bryum pseudotriquetrum is a minor or absent (Ohtani et al. 2001). The moss pillar samples used in this study may not contain the genus Bryum.

Most dominant fungi in moss pillars

The 622 sequences belonging to Fungi (approximately $56 \%$ ) were classified into 7 phylotypes that were exceedingly dominant in all 14 samples (both interior and exterior layers) (Table 1). Furthermore, all phylotypes obtained had a homology of $<90 \%$ with the 18S rRNA gene sequences of known, cultured fungi species, thus showing their novelty. Of the 7 phylotypes, MPE1-17 (574 clones) was dominant and had a $92.4 \%$ homology with a closely related environmental clone (FR874399) obtained from the coastal waters of fjords. This phylotype, another 4 phylotypes (MPE1-18, MPE1-20, MPE1-22, and MPE123), and 4 environmental clones formed a novel clade within our phylogenetic tree (Fig. S1). The MPE1-17 had an $86.1 \%$ homology with the $18 \mathrm{~S}$ rRNA gene sequence from Entophlyctis helioformis isolate AFTOL-ID 40 (AY635826) (Chytridiales); this was the nearest relative among known cultured fungi. In addition, MPE1-23, obtained in this study, shows a relatively high homology (88.9\%) with Hyaloraphidium curvatum of the known Chytridiomycota (chytrids). 
Fig. 2 Rarefaction curves for phylotypes and PCR clones of the 18S rRNA gene from the specimens $\mathrm{A}$ and $\mathrm{B}$
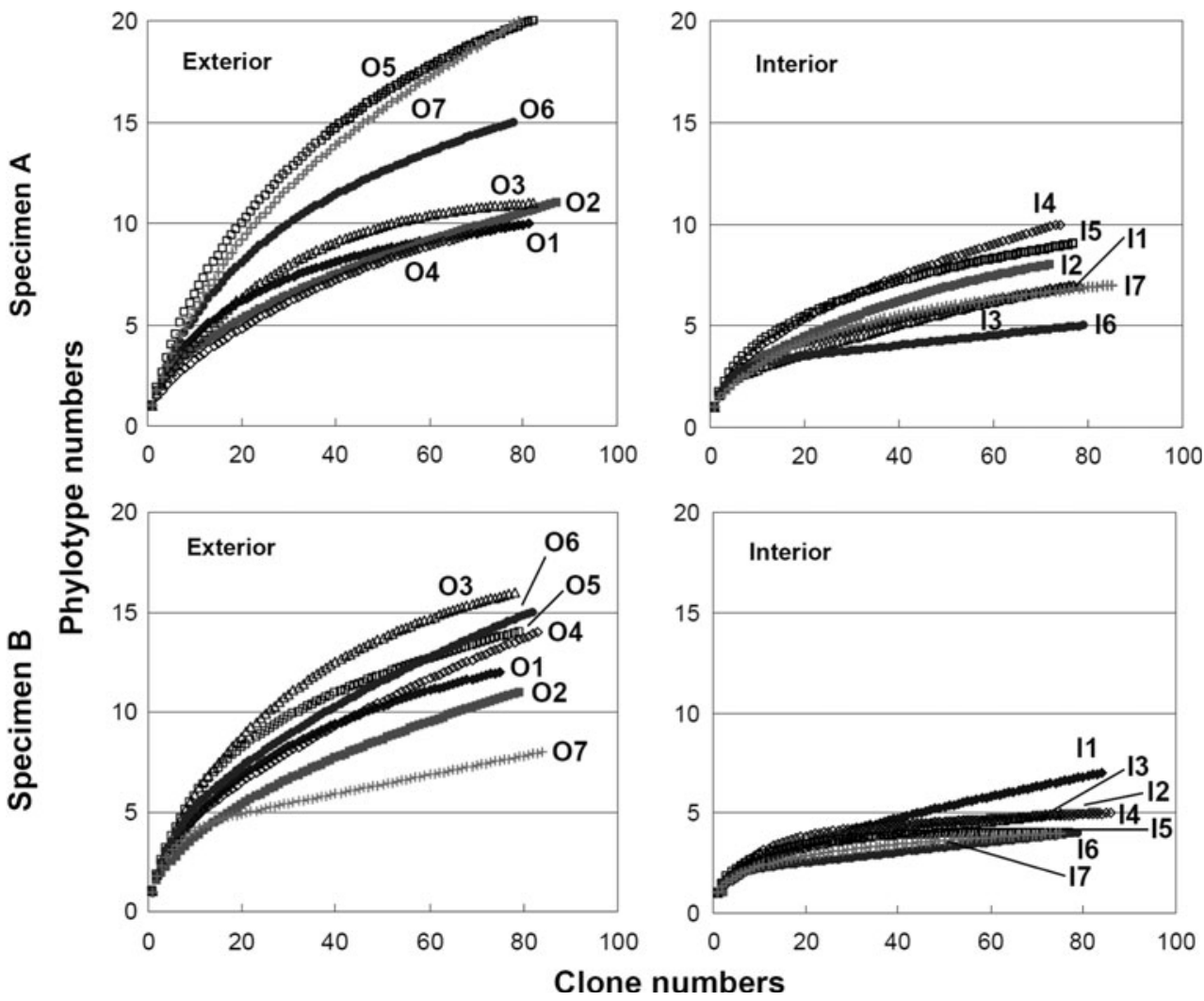

Chytrids are common fungi that are found in aquatic habitats and moist soil; some are parasitic on mosses, algae, and tardigrades, while others are saprophytes (Dewel et al. 1985; Gleason et al. 2008). Because parasitic chytrids are able to penetrate and grow within their hosts, they may exert an effect on the eukaryotic microbiota. Saprophytes decompose organic matter in water and soil and obtain nutrients. Some saprophytes can degrade refractory organic substrates such as cellulose and are considered to play a key role in the carbon cycle (Gleason et al. 2008). Freeman et al. (2009) reported that in soil at high altitudes such as in the Himalayan and Rocky Mountains, and on Alexander Island on the western Antarctic Peninsula, sequences that are closely related to chytrids are more than $70 \%$ of the fungal sequences, elucidating the presence of unique ecosystems dominated by chytrids. This study also shows that a novel clade of fungi is exceedingly dominant (approximately 27-75 \%) in the clone library from moss pillar samples. This suggests that these fungi could play a key role in establishing and maintaining moss pillars if they are involved as parasites or decomposers.

\section{Alveolata, Metazoa, and Rhizaria detected in moss pillars}

The 92 sequences belonging to Alveolata (approximately $8 \%$ ) were classified into 13 phylotypes (Table 1). Among these, phylotypes ( 81 clones) closely related to ciliates were dominant and detected in both exterior and interior layers of moss pillars. Ciliates are capable of feeding on bacteria, and some are known to be able to grow in anaerobic environments (Fenchel and Finlay 1995). In our study, phylotypes closely related to ciliates in the Oxytrichidae family, known for growth in anaerobic environments (Schwarz and Frenzel 2003), were obtained from the reductive interior. This implies that some ciliates may be the main bacterial predators in the interior of moss pillars. In general, anaerobic ciliates contain symbiotic methaneproducing bacteria or purple bacteria (Fenchel and Finlay 1995). These endosymbionts are in charge of most of energy transformation under anaerobic conditions. Although the sequences related to methane-producing bacteria were not detected in previous 16S rRNA gene analysis (Nakai et al. 2012), sequences related to purple bacteria were obtained. Anaerobic ciliates detected in this study may contain similar symbiotic bacteria.

The 85 sequences belonging to Metazoa (approximately $8 \%$ ) were classified into 8 phylotypes (Table 1). Of these, 2 phylotypes (71 clones) closely related to tardigrades were dominant, and approximately $90 \%$ of detected clones were obtained from the exterior layer of the moss pillars. The first phylotype, MPE1-42 (49/71 clones), had a relatively high homology $(98.8 \%)$ with the $18 \mathrm{~S}$ rRNA gene 
sequence from the known species Diphascon pingue (FJ435736). The second phylotype, MPE1-43, showed a $99.8 \%$ homology with the known species Acutuncus antarcticus isolate Acut_06_262 (EU266943). Both of these tardigrades are found not only in East Antarctica but also in Graham Land (northern Antarctic Peninsula), South Orkney Islands (maritime Antarctica), and South Georgia Island (sub-Antarctica) (Convey and Mcinnes 2005), thus indicating that the species is widely distributed through Antarctica. The phylotypes found in the exterior and belonging to Metazoa also included some phylophytes with a relatively high homology $(\geq 97.7 \%)$ with known genera of nematode and rotifers, indicating that the exterior layers are habitats not only for tardigrades but also for a variety of small animals.

The 10 sequences belonging to Rhizaria (approximately $1 \%$ ) were classified into 3 phylotypes (Table 1). These phylotypes all belong to the genus Cercozoa, and a phylotype with a high homology $(98.4 \%)$ to the $18 \mathrm{~S}$ rRNA gene sequence of Cercomonas alexieffi (AF411267) was found to exist specifically in the interior layer. The genus Cercomonas is an ameba-like, single-celled eukaryote, and some of its species are reported to grow under anaerobic conditions. In fact, sequences related to Cercomonas have been detected from anaerobic environments (Murase et al. 2006). This suggests that some species of Cercomonas may be the main bacterial predators in the reductive interior, similar to the ciliates of the Oxytrichidae family as previously mentioned; this may affect bacterial species composition of the interior of moss pillars.

\section{Stramenopiles detected in moss pillars}

The 27 sequences belonging to Stramenopiles (approximately $2 \%$ ) were classified into 10 phylotypes (Table 1). Of these phylotypes, the dominant sequences were closely related to the unicellular heterotrophic fungoid-like eukaryote Labyrinthulida, which forms an independent cluster in the phylogenetic tree. Microorganisms that are classified as Labyrinthulida are generally known to exist in oceans, especially along coastal areas (Raghukumar 2002), although freshwater taxa/species/organisms are also known (Tong et al. 1997). These microorganisms can decompose easily degradable organic matter, such as starch and fatty acids, and refractory organic matter, such as cellulose (Raghukumar 2002). Accordingly, although their biomass may be small, it is highly possible that these microorganisms are involved in the decomposition of dead moss and algae. Furthermore, Labyrinthulida have approximately $10^{3}$ times greater biovolume than bacteria (Kimura and Naganuma 2001). Considering that they can be directly preyed upon by large ciliates and accumulate fatty acids inside their bodies at high levels (Kimura and Naganuma
2001), these microorganisms may be enhancing the transfer efficiencies within food webs in moss pillars.

One phylotype (3 clones) was closely related $(98.5 \%)$ to the 18S rRNA gene sequence from a golden-brown alga Ochromonas sphaerocystis (AF123294) (Chrysophyta). Thus, this study detected not only the sequences related to heterotrophic stramenopiles but also those related to autotrophic stramenopiles.

Comparison of eukaryotic community composition between moss pillars

To confirm the reproducibility of our genetic analysis of moss pillar specimen $\mathrm{A}$, and to compare the eukaryotic microbiota between moss pillars, we attempted to obtain near-full-length 18S rRNA genes from moss pillar specimen B. A total of 1,344 clones were obtained from specimen B for analysis, of which 1,119 could be used for phylotyping after excluding unclear sequence waveforms and chimeric sequences. These yielded 44 phylotypes $(\geq 97 \%$ ) that were compared with 52 phylotypes obtained from specimen A. As a result, specimen B had 18 phylotypes (based on the $97 \%$ criterion) in common with specimen A. In other words, 34 phylotypes were found only in specimen A, 26 were found only in specimen B, and 18 were common (Table 2; distribution, phylogenetic classification, and BLASTN homology search results for phylotypes from specimen B are shown in Tables S2, S3, and S4; the phylogenetic tree of phylotypes is shown in Fig. S1). The number of common phylotypes corresponds to $35 \%$ of specimen A phylotypes and $41 \%$ of specimen B phylotypes. The common phylotypes in both specimens were phylogenetically classified into 9 phylotype groups: 1 Bryophyta, 5 Alveolata (1 Apicomplexa, 4 Ciliophora), 3 Amoebozoa (2 Tubulinea, 1 unclassified Amoebozoa), 1 Chlorophyta, 1 Fungi, 2 Metazoa (1 Rotifera, 1 Tardigrada), 1 Rhizaria, 1 Rhodophyta, and 3 Stramenopiles (1 Labyrinthulida, 1 Oikomonadaceae, 1 unclassified Stramenopile) (Table 2). According to a report by Imura et al. (2000), it takes approximately 300 years for a moss pillar to grow to $20 \mathrm{~cm}$ in height. The specimens $\mathrm{A}$ and $\mathrm{B}$ used in this study would require 450 and 400 years, respectively, for this amount of growth. This suggests that even though the pillars inhabit the same lake, these were at different growth stages. Therefore, the difference in eukaryotic microbiota between moss pillars may be dependent upon the microorganisms that immigrate to the structure in the growth stage. Additionally, the microheterogeneity of the community within each moss pillar may have affected our results. However, surprisingly, there are common phylotypes among individuals; the commonalities can be considered to indicate certain trends in eukaryotic community structure. 
Table 2 Distribution of unique and common phylotypes (based on the $97 \%$-criterion) among 18S rRNA gene libraries from the specimens $\mathrm{A}$ and $\mathrm{B}$

\begin{tabular}{|c|c|c|c|c|c|c|}
\hline Phylogenetic group & $\mathrm{A}^{\mathrm{a}}$ & $\begin{array}{l}\text { Breakdown of the closest } \\
\text { sequence/organism }\end{array}$ & $\mathrm{B}^{\mathrm{b}}$ & $\begin{array}{l}\text { Breakdown of the closest } \\
\text { sequence/organism }\end{array}$ & $\mathrm{C}^{\mathrm{c}}$ & $\begin{array}{l}\text { Breakdown of the closest } \\
\text { sequence/organism }\end{array}$ \\
\hline Bryophyta & 0 & & 0 & & 1 & Leptobryum pyriforme \\
\hline Alveolata & 8 & & 6 & & 5 & \\
\hline Apicomplexa & $(0)$ & & $(0)$ & & (1) & Lake clone \\
\hline Ciliophora & (6) & $\begin{array}{l}\text { Homalogastra setosa, Bursaria } \\
\text { truncatella, Cyrtolophosis } \\
\text { mucicola, two rhizosphere } \\
\text { clones, sea ice clone }\end{array}$ & (4) & $\begin{array}{l}\text { Lacrymaria marina, Semispathidium sp., } \\
\text { Spathidium stammeri, sea ice clone }\end{array}$ & (4) & $\begin{array}{l}\text { Halteria grandinella, } \\
\text { Obertrumia georgiana, } \\
\text { Onychodromopsis } \\
\text { flexilis, Oxytricha longa }\end{array}$ \\
\hline Dinophyceae & (0) & & (1) & Karlodinium micrum & (0) & \\
\hline $\begin{array}{l}\text { Unclassified } \\
\text { Alveolata }\end{array}$ & (2) & $\begin{array}{l}\text { Colpodella edax, Ochromonas } \\
\text { sp. }\end{array}$ & (1) & Lake clone & (0) & \\
\hline Amoebozoa & 4 & & 0 & & 3 & \\
\hline Mycetozoa & (1) & $\begin{array}{l}\text { Schizoplasmodium } \\
\text { cavostelioides }\end{array}$ & $(0)$ & & $(0)$ & \\
\hline Tubulinea & $(0)$ & & $(0)$ & & (2) & $\begin{array}{l}\text { Gephyramoeba sp., } \\
\text { Lobosea sp. }\end{array}$ \\
\hline $\begin{array}{l}\text { Unclassified } \\
\text { Amoebozoa }\end{array}$ & (3) & $\begin{array}{l}\text { Ceratiomyxella tahitiensis, } \\
\text { marine clone, soil clone }\end{array}$ & $(0)$ & & (1) & Soil clone \\
\hline Chlorophyta & 0 & & 2 & $\begin{array}{l}\text { Chlamydomonas perpusilla, Coenocystis } \\
\text { inconstans }\end{array}$ & 1 & $\begin{array}{l}\text { Chlamydomonas } \\
\text { reinhardtii }\end{array}$ \\
\hline Fungi & 6 & $\begin{array}{l}\text { Two lake clones, marine } \\
\text { sediment clone, two } \\
\text { rhizosphere clones, sulfide- } \\
\text { rich spring clone }\end{array}$ & 5 & $\begin{array}{l}\text { Madurella sp., lake clone, marine clone, } \\
\text { rhizosphere clone, soil clone }\end{array}$ & 1 & Marine clone \\
\hline Metazoa & 6 & & 0 & & 2 & \\
\hline Nematoda & (1) & Plectidae sp. & (0) & & $(0)$ & \\
\hline Platyhelminthes & (2) & $\begin{array}{l}\text { Castrada viridis, Mesostoma } \\
\text { lingua }\end{array}$ & $(0)$ & & $(0)$ & \\
\hline Rotifera & $(0)$ & & $(0)$ & & (1) & Lepadella patella \\
\hline Tardigrada & (1) & Acutuncus antarcticus & $(0)$ & & (1) & Diphascon pingue \\
\hline Unclassified Metazoa & (2) & $\begin{array}{l}\text { Acutuncus antarcticus, } \\
\text { Diphascon pingue }\end{array}$ & $(0)$ & & (0) & \\
\hline Rhizaria & 2 & $\begin{array}{l}\text { Cercozoa sp., rhizosphere } \\
\text { clone }\end{array}$ & 10 & $\begin{array}{l}\text { Cercomonas alexieffi, Cryothecomonas } \\
\text { longipes, Eocercomonas echina, } \\
\text { Paracercomonas oxoniensis, Paulinella } \\
\text { chromatophora, peat clone, three } \\
\text { rhizosphere clones, sea ice clone }\end{array}$ & 1 & Cercomonas alexieffi \\
\hline Rhodophyta & 1 & Cyanidioschyzon sp. & 1 & Cyanidioschyzon sp. & 1 & Cyanidioschyzon sp. \\
\hline Stramenopiles & 7 & & 2 & & 3 & \\
\hline Chrysophyceae & (1) & Ochromonas sphaerocystis & (1) & Chrysosaccus sp. & (0) & \\
\hline Dictyochophyceae & (2) & Pteridomonas danica & $(0)$ & & (0) & \\
\hline Hyphochytriomycetes & (1) & Hyphochytrium catenoides & $(0)$ & & $(0)$ & \\
\hline Labyrinthulida & (2) & $\begin{array}{l}\text { Aplanochytrium kerguelense, } \\
\text { marine clone }\end{array}$ & (1) & Marine clone & (1) & Marine clone \\
\hline Oikomonadaceae & $(0)$ & & $(0)$ & & (1) & Lake clone \\
\hline Oomycetes & (1) & Pythiaceae sp. & $(0)$ & & (0) & \\
\hline $\begin{array}{l}\text { Unclassified } \\
\text { Stramenopiles }\end{array}$ & $(0)$ & & $(0)$ & & (1) & Rhizosphere clone \\
\hline Total & 34 & & 26 & & 18 & \\
\hline
\end{tabular}

Numbers from respective "Alveolata," "Amoebozoa," "Metazoa," and "Stramenopiles" phylotypes are in parentheses

a Unique phylotypes to the specimen A's $18 \mathrm{~S}$ rRNA gene libraries

b Unique phylotypes to the specimen B's 18S rRNA gene libraries

${ }^{\mathrm{c}}$ Common phylotypes between 18S rRNA gene libraries from the specimens A and B 
The sequences belonging to Bryophyta obtained from specimens A and B had a $100 \%$ match. Furthermore, the following features were shared by both specimens: a novel clade of fungi was exceedingly dominant in both entire moss pillars; the phylotypes belonging to ciliates and tardigrades were subdominant in the exterior layers; and the phylotype of the ameba-like, single-celled eukaryote, Cercomonas (Cercozoa), was also detected only in the interior (Tables S1 and S3). From the above, it seems highly probable that some eukaryotic phylotypes showed pillar-wide distributions, while others were section-specific.

However, the frequency of detection of ciliates (Alveolata) in the exterior differed between specimens, as reflected in clone occupancies of 3.3 and $6.8 \%$ of total clones in specimens A and B, respectively. The moss pillar exterior is in direct contact with lake water, and it is highly probable that the eukaryotic phylotypes are partially shared with those present planktonically in the lake water. This may be indicated by the phylogenetic groupings in our analysis. In fact, the phylotype closely related to the known planktonic ciliate Halteria grandinella was detected only in the exterior of both moss pillars. Furthermore, the frequency of detection of tardigrades (Metazoa) was $6.4 \%$ for specimen A and $12.3 \%$ for specimen B with some discrepancy between the specimens. The difference in benthic animals between moss pillars may be dependent upon the microorganisms that immigrate to the structure in the growth stage as previously described. Rarefaction analysis showed that specimen $\mathrm{B}$, like specimen $\mathrm{A}$, showed potentially higher biodiversity on the exterior part of the moss pillar than on the interior part (Fig. 2). This conclusion was further supported by the average values of the Shannon index for the exterior (1.78) and the interior (0.80) parts of the moss pillar (Tables 1 and S2).

\section{Conclusion}

Our study shows that moss pillars contain not only moss and algae but also fungi and various small animals, as determined by molecular phylogenetic analysis of $18 \mathrm{~S}$ rRNA gene sequences using two whole moss pillars. It appears highly probable that autotrophic green algae, red algae, and golden-brown algae function as primary producers, while fungi, ciliates, and Labyrinthulida function as parasites or decomposers in establishing and maintaining these ecosystems. However, we have isolated the DNA from both benthic and planktonic cellular debris and undegraded biological materials. In future, we intend to identify the living organisms that were actually playing an ecological role with the help of morphological studies. Of all 78 phylotypes obtained, 47 (approximately $60 \%$ ) have a below $95 \%$ homology with known genera and species, suggesting novel taxa at species, genera, or class levels. We also found the existence of unclassified Alveolata, Amoebozoa, Metazoa, and Stramenopiles. The moss pillar ecosystems unique to Antarctic lakes clearly have eukaryotic microbiota with extremely high phylogenetic novelty. To elucidate genetic and physiological characteristics of the exceedingly dominant fungi in moss pillars, isolation, culturing, and genome analysis are required.

Acknowledgments We gratefully acknowledge the members of the 42nd Japanese Antarctic Research Expedition (JARE). We thank Kazuko Ohishi and Tadasu Shin-i for their excellent technical help. This study was supported by the National Polar Research Institute and the Transdisciplinary Research Integration Center, Research Organization of Information and Systems, Japan. The study was conducted as part of the Microbiological and Ecological Responses to Global Environmental Changes in Polar Regions (MERGE) program during the International Polar Year of 2007-2008.

Open Access This article is distributed under the terms of the Creative Commons Attribution License which permits any use, distribution, and reproduction in any medium, provided the original author(s) and the source are credited.

\section{References}

Altschul SF, Madden TL, Schaffer AA, Zhang J, Zhang Z, Miller W, Lipman DJ (1997) Gapped BLAST and PSI-BLAST: a new generation of protein database search programs. Nucleic Acids Res 25:3389-3402

Amann RI, Binder BJ, Olson RJ, Chisholm SW, Devereux R, Stahl DA (1990) Combination of 16S rRNA-targeted oligonucleotide probes with flow cytometry for analyzing mixed microbial populations. Appl Environ Microbiol 56:1919-1925

Cavalier-Smith T (2005) Economy, speed and size matter: evolutionary forces driving nuclear genome miniaturization and expansion. Ann Bot 95:147-175

Convey P (2006) Antarctic climate change and its influences on terrestrial ecosystems. In: Bergstrom DM, Convey P, Huiskes AHL (eds) Trends in Antarctic terrestrial and limnetic ecosystems: Antarctica as a global indicator. Springer, Dordrecht, pp 253-272

Convey P (2011) Antarctic terrestrial biodiversity in a changing world. Polar Biol 34:1629-1641

Convey P, McInnes SJ (2005) Exceptional tardigrade-dominated ecosystems in Ellsworth Land, Antarctica. Ecology 86:519-527

DeLong EF (1992) Archaea in coastal marine environment. Proc Natl Acad Sci USA 89:5685-5689

Dewel RA, Joines JD, Bond JJ (1985) A new chytridiomycete parasitizing the tardigrade Milnesium tardigradum. Can J Bot 63:1525-1534

Fenchel T, Finlay BJ (1995) Ecology and evolution in Anoxic Worlds. Oxford University Press, Oxford

Freeman KR, Martin AP, Karki D, Lynch RC, Mitter MS, Meyer AF, Longcore JE, Simmons DR, Schmidt SK (2009) Evidence that chytrids dominate fungal communities in high-elevation soils. Proc Natl Acad Sci USA 106:18315-18320

Gibson JAE, Wilmotte A, Taton A, van de Vijver B, Beyens L, Dartnall HJG (2006) Biogeography of Antarctic lakes. In: Bergstrom DM, Convey P, Huiskes AHL (eds) Trends in Antarctic terrestrial and limnetic ecosystems: Antartica as a global indicator. Springer, Dordrecht, pp 71-98 
Gleason FH, Kagam M, Lefèvre E, Sime-Ngando T (2008) The ecology of chytrids in aquatic ecosystems: roles in food web dynamics. Fungal Biol Rev 22:17-25

Huang Y, Niu BF, Gao Y, Fu LM, Li WZ (2010) CD-HIT Suite: a web server for clustering and comparing biological sequences. Bioinformatics 26:680-682

Huber T, Faulkner G, Hugenholtz P (2004) Bellerophon: a program to detect chimeric sequences in multiple sequence alignments. Bioinformatics 20:2317-2319

Imura S (2006) Ecosystem and geohistory of Antarctic lakes. Abstracts for XIII Int Symp Polar Sciences, Incheon, pp 108-111

Imura S, Bando T, Saito S, Seto K, Kanda H (1999) Benthic moss pillars in Antarctic lakes. Polar Biol 22:137-140

Imura S, Takahashi H, Nakamura T (2000) Benthic moss pillars (Koke Bouzu) in Antarctic lakes-Analysis of colonization and growth by ${ }^{14} \mathrm{C}$ dating. Sum Res using AMS, Nagoya Univ XI:176-183 (in Japanese with English Abstract)

Imura S, Bando S, Seto K, Ohtani S, Kudoh S, Kanda H (2003) Distribution of aquatic mosses in the Syowa Coast region, East Antarctica. Polar Biosci 16:1-10

Iwasa T, Bando T, Nakamura T, Imura S (2000) The environmental changes presumed by AMS ${ }^{14} \mathrm{C}$ ages of algal sediments in Antarctic lakes, near the Syowa Station. Sum Res using AMS, Nagoya Univ XI:74-80 (in Japanese with English Abstract)

Kimura H, Naganuma T (2001) Thraustochytrids: a forgotten agent of the marine microbial food chain. Aquat Ecosyst Health \& Management 4:13-18

Kimura S, Ban S, Imura S, Kudoh S, Matsuzaki M (2010) Limnological characteristics of vertical structure in the lakes of Syowa oasis, East Antarctica. Polar Sci 3:262-271

Kudoh S, Tuchiya Y, Ayukawa E, Imura S, Kanda H (2003a) Ecological studies of aquatic moss pillars in Antarctic lakes. 1: macro structure and carbon, nitrogen and chlorophyll $a$ contents. Polar Biosci 16:11-22

Kudoh S, Watanabe K, Imura S (2003b) Ecological studies of aquatic moss pillars in Antarctic lakes. 2: temperature and light environment at the moss habitat. Polar Biosci 16:23-32

Kudoh S, Kashino Y, Imura S (2003c) Ecological studies of aquatic moss pillars in Antarctic lakes. 3: light response and chilling and heat sensitivity of photosynthesis. Polar Biosci 16:33-42

Kudoh S, Tanabe Y, Matsuzaki M, Imura S (2009) In situ photochemical activity of the phytobenthic communities in two Antarctic lakes. Polar Biol 32:1617-1627

Laybourn-Parry J (2009) No place too cold. Science 324:1521-1522

Li W, Godzik A (2006) Cd-hit: a fast program for clustering and comparing large sets of protein or nucleotide sequences. Bioinformatics 22:1658-1659

Maidak BL, Cole JR, Lilburn TG, Parker CT Jr, Saxman PR, Farris RJ, Garrity GM, Olsen GJ, Schmidt TM, Tiedje JM (2001) The RDP-II (Ribosomal Database Project). Nucleic Acids Res 29: 173-174

Matsumoto GI, Komori K, Enomoto A, Imura S, Takemura T, Ohyama Y, Kanda H (2006) Environmental changes in Syowa Station area of Antarctica during the last 2,300 years inferred from organic components in lake sediment cores. Polar Biosci 19:51-62
Medlin L, Elwood HJ, Stickel S, Sogin ML (1988) The characterization of enzymatically amplified eukaryotic 16S-like rRNAcoding regions. Gene 71:491-499

Miller DN, Bryant JE, Madsen EL, Ghiorse WC (1999) Evaluation and optimization of DNA extraction and purification procedures for soil and sediment samples. Appl Environ Microbiol 65:47154724

Murase J, Noll M, Frenzel P (2006) Impact of protists on the activity and structure of the bacterial community in a rice field soil. Appl Environ Microbiol 72:5436-5444

Nakai R, Abe T, Baba T, Imura S, Kagoshima H, Kanda H, Kanekiyo A, Kohara Y, Koi A, Nakamura K, Narita T, Niki H, Yanagihara K, Naganuma T (2012) Microflorae of aquatic moss pillars in a freshwater lake, East Antarctica, based on fatty acid and 16S rRNA gene analyses. Polar Biol 35:425-433

Nakanishi S (1977) Ecological studies of the moss and lichen communities in the ice-free areas near Syowa station, Antarctica. Antarct Rec 59:68-96

Ohtani S, Kudoh S, Tsuchiya Y, Suyama K, Imura S (2001) Species composition of freshwater algae in benthic moss pillars in lakes, Skarvsnes, Antarctica. Abstracts for XXIV Symp Polar Biol Tokyo, Natl Inst Polar Res, p 77

Potvin M, Lovejoy C (2009) PCR-based diversity estimates of artificial and environmental 18S rRNA gene libraries. J Eukaryot Microbiol 56:174-181

Quesada A, Fernandez-Valiente E, Hawes I, Howard-Williams C (2008) Benthic primary production in polar lakes and rivers. In: Vincent WF, Laybourn-Parry J (eds) Polar lakes and rivers. Oxford University Press, Oxford, pp 179-196

Raghukumar S (2002) Ecology of the marine protists, the Labyrinthulomycetes (Thraustochytrids and Labyrinthulids). Eur J Protistol 38:127-145

Schwarz MVJ, Frenzel P (2003) Population dynamics and ecology of ciliates (Protozoa, Ciliophora) in an anoxic rice field soil. Biol Fertil Soils 38:245-252

Tamura K, Peterson D, Peterson N, Stecher G, Nei M, Kumar S (2011) MEGA5: molecular evolutionary genetics analysis using maximum likelihood, evolutionary distance, and maximum parsimony methods. Mol Biol Evol 28:2731-2739

Tanabe Y, Kudoh S, Imura S, Fukuchi M (2008) Phytoplankton blooms under dim and cold conditions in freshwater lakes of East Antarctica. Polar Biol 31:199-208

Tewari SD, Pant G (1996) Some moss collections from Dakshin Gangotri, Antarctica. Bryol Times 91:7

Tong S, Vors N, Patterson DJ (1997) Heterotrophic flagellates, centrohelid heliozoa and filose amoebae from marine and freshwater sites in the Antarctic. Polar Biol 18:91-106

Vincent WF (1988) Microbial ecosystems of Antarctica. Cambridge University Press, Cambridge

Vincent WF (2000) Cyanobacterial dominance in the polar regions. In: Whitton BA, Potts M (eds) The ecology of cyanobacteria: their diversity in time and space. Kluwer, Dordrecht, pp 321-340

Zhu F, Massana R, Not F, Marie D, Vaulot D (2005) Mapping of picoeucaryotes in marine ecosystems with quantitative PCR of the 18S rRNA gene. FEMS Microbiol Ecol 52:79-92 